\title{
環境水中のフェノール類の高速液体クロマトグラフィー のための新しい誘導体化前濃縮法
}

\author{
伊藤 純一 ${ }^{\circledR}$ ，㕕沢 幸弘，小俣 雅嗣 ${ }^{*}$
}

(1994 年 6 月 21 日受理)

\begin{abstract}
フェノール類を4-スルホベンゼンジアゾニウム塩とジアゾカップリングさせ，生成した色素と第四 級アンモ二ウム塩とのイオン会合体を形成させ，このイオン会合体の凝集をメンブランフィルターを装 着したラインフィルターにオンラインで前濃縮し HPLC で分析する方法を開発した。この方法により 数 $\mu \mathrm{g} \mathrm{dm}{ }^{-3}$ レベルのフェノール, $o-, m-$ クレゾール,$m-$ クロロフェノール,$o-, m$-エチルフェノール 及び 2,3-, 2,5-キシレノールの 8 種のフェノ一ル類が相互に分離され定量できた. 色素は膜表面にほ之 んぜ体積を持たずに濃縮されるため非常に高い濃縮率が得られ，又オンラインーミニカラム濃縮法に比 ベ分離度の高いクロマトグラムが得られた。このイオン会合体試料の $2 \mathrm{~cm}^{3}$ を濃縮した場合検出限界 $(S / N=3)$ は, 最も感度の高いフェノールが $40 \mathrm{ng} \mathrm{dm}^{-3}$, 最も感度の低い 2,5-キシレノールが $2 \mu \mathrm{g}$ $\mathrm{dm}^{-3}$ であった. 又, 本法を用いて 8 種のフェノール類の河川水からの回収分離定量を行った.
\end{abstract}

\section{1 緒言}

環境中におけるフェノール類は，工場排水ばかりでな く家庭からの下水中㠳や喫煙室内の空気からも見いださ れている21.これら微量のフェノールの分離分析は環境 水の污濁や大気の污染を知る上で重要である.

排水中のフェノールの定量の公定法としては 4-アミ ノアンチピリン吸光光度法 ${ }^{3 / 4)}$ が採用されている.この 定量法は溶媒抽出を併用することにより高感度で定量で きるが,クレゾール等幾つかのフェノール類が同時発色 し，それらの合量を測定するものであり，それぞれ発色 率, 吸光係数が違うことからかなりあいまいな定量法之 いえる. HPLCによるフェノール類の分離定量には, 吸光係数を增大させるための誘導体化が重要である.

Kuwata らは大気中のフェノールをp-ニトロベンゼンア ゾフェノールに誘導体化して HPLCによって高感度分 析を行った2)5.

近年，有色金属キレートと第四級アンモニウム塩との イオン会合体をメンブランフィルターに捕集し，これを 少量の有機溶媒にフィルターごと再溶解し吸光光度法6) や $\mathrm{AAS}^{7}$ の試料とする前濃縮法が報告されている。著 者らはポリ四フッ化エチレン（PTFE）製メンブランフ イルターを装着したラインフィルターをインジェクショ

* 北見工業大学化学システム工学科: 090 北海道北見市 公園町 165
ンバルブに取り付けた HPLC を考案し，これにより2(5-ブロモ-2-ピリジルアゾ)-5(N-プロピル- $N$-スルホプロ ピルアミノ)アニリン金属キレートイオンとベンジルジ メチル(テトラデシル)アンモニウムニクロリド(ゼフィラ ミン)とのイオン会合体をオンラインで膜濃縮した後分 離分析した ${ }^{8)}$.

本研究は種々のフェノール類を4-スルホベンゼンジ アゾニウム塩とジアゾカップリングさせて吸光係数を増 大させた後, これとゼフィラミンとのイオン会合体を形 成させ，このイオン会合体の凝集をオンラインで前述の ラインフィルターに濃縮して HPLC で分析する方法に ついて検討した。 その結果, 8 種のフェノール類につい て 4-アミノアンチピリン吸光光度法より高感度で分離 定量できることが分かった。

$$
2 \text { 実験 }
$$

\section{$2 \cdot 1$ 試 薬}

4-スルホベンゼンジアゾニウム水溶液は, 4-スルホベ ンゼンアニリン $0.19 \mathrm{~g}$ を蒸留水 $50 \mathrm{~cm}^{3}$ で溶解した後水 冷し, 塩酸 $1 \mathrm{~cm}^{3}$ を加え次いで $0.2 \%$ 带硝酸ナトリウ 么水溶液 $50 \mathrm{~cm}^{3}$ を加え調製した。これらの試薬は和光 純薬工業製試薬特級を用いた。 $1 \times 10^{-2} \mathrm{~mol} \mathrm{dm}^{-3}$ ゼフ イラミン水溶液は, 同仁化学研究所製ゼフィラミン $0.404 \mathrm{~g}$ を蒸留水 $100 \mathrm{~cm}^{3}$ に溶解して用いた.

移動相溶液は和光純薬工業製 HPLC 用アセトニトリ 
ル $37.5(\mathrm{v} / \mathrm{v}) \%$ 及び $1.6 \times 10^{-4} \mathrm{~mol} \mathrm{dm}{ }^{-3}$ ゼフィラミ ン, $8.0 \times 10^{-3} \mathrm{~mol} \mathrm{dm}^{-3}$ 酢酸緩衝液 $(\mathrm{pH} \mathrm{4.6)}$ を含む 水溶液 $62.5(\mathrm{v} / \mathrm{v}) \%$ を用いた。

フェノール類は，市販の試薬特級又はそれに準ずるグ レードのものを用い, $0.1 \mathrm{~g}$ を蒸留水 $100 \mathrm{~cm}^{3}$ に溶解し て標準溶液を調製し，適宜希釈して用いた。

その他の試薬は市販の試薬特級を用いた.

\section{$2 \cdot 2$ 装 置}

HPLC はポンプ (CCPD 東ソ一製), 吸光検出器 (L-3000 日立製作所製)，インジェクター (Rheodyne $7125)$ で構成した。インジェクター部には前濃縮のため に Fig. 1 に示す PTFE 製メンブランフィルター(アド バンテック東洋製, 孔径 $0.5 \mu \mathrm{m}$ を直径 $6 \mathrm{~mm}$ に切った もの) を装着したラインソルベントフィルター(ジーエ ルサイエンス製), 又は Nucleosil C-18 (ナーゲル製) を 充てんしたミニカラム $(4.6$ i.d. $\times 10 \mathrm{~mm}$ ，ジ一エルサイ エンス製) を接続し使用した. 分析カラムは TSKgel ODS-120 T (4.6 i.d. $\times 250 \mathrm{~mm}$ ，東ソ一製）を用いた.

アゾフェノールのスペクトル測定には島津製作所製 UV-2200 分光光度計を使用した。

\section{$2 \cdot 3$ 定量操作}

フェノール類を $2.5 \mu \mathrm{g}$ 以下を含む溶液 $40 \mathrm{~cm}^{3}$ に $\mathrm{pH}$ 10.5 になるように $0.2 \mathrm{~mol} \mathrm{dm}^{-3}$ 炭酸緩衝液 $1 \mathrm{~cm}^{3}, 4-$ スルホベンゼンジアゾニウム水溶液を $0.5 \mathrm{~cm}^{3}$ 加え 3 分間放置する。これに $1 \mathrm{~mol} \mathrm{dm}{ }^{-3}$ 酢酸緩衝液 $0.25 \mathrm{~cm}^{3}$ を加え $\mathrm{pH} 5$ とした後, ゼフィラミン水溶液 $0.5 \mathrm{~cm}^{3}$ 及 び蒸留水を加えて $50 \mathrm{~cm}^{3}$ とし振り混ぜて 10 分間放置 する。この溶液をガスタイトシリンジを用いて $3 \mathrm{~cm}^{3}$ までの適量を HPLC のインジェクションポートよりラ インフィルターに前濃縮する。流路を切り替え溶離液を 流量 $\mathrm{l} \mathrm{cm}^{3} \mathrm{~min}^{-1}$ で溶出し, 分離力ラムを経て波長 352 $\mathrm{nm}$ で吸光度を測定する. 分離カラムの恒温槽は, $35^{\circ} \mathrm{C}$ に保った。

\section{3 結果及び考察}

\section{$3 \cdot 1$ 誘導体化の予備実験}

一価フェノール 19 種類及び多価フェノール 3 種類に ついて検討した。 その結果, 数種のフェノール及び多価 フェノールは，ジアゾカップリング反応において複数の 異性体を生成し，又イオン会合体も $1: 1$ 会合体以外の ものを形成するためと考えられる複数のピークを示すク ロマトグラムが観測された。それぞれ再現性があり定性 分析には有用と考えられるが，ここでは分離定量が可能
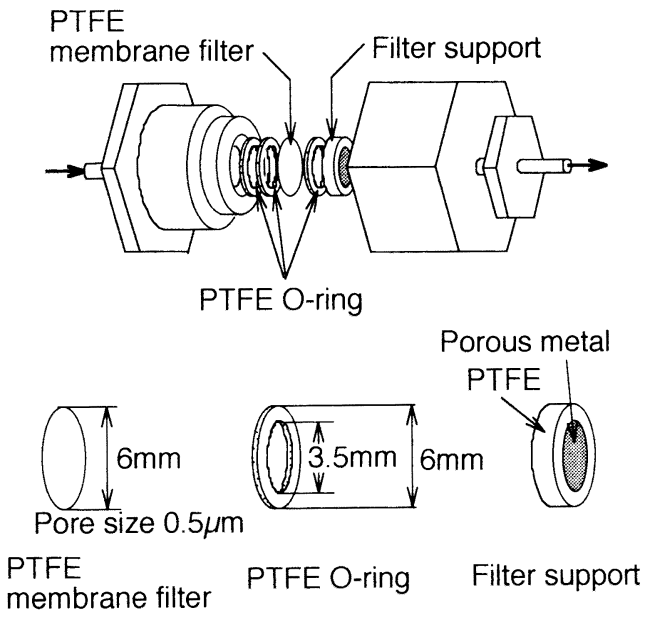

Fig. 1 Linefilter

な単一ピークを示す 8 種類の一価フェノールについて 検討した。なお，フェノールは他の検討したフェノール 類から離れて最初に溶出するためその定量は妨害されな w.

\section{$3 \cdot 2$ ジアゾカップリング反応の諸条件の検討}

ジアゾニウム塩の添加量がアゾフェノール誘導体の生 成に与える影響について HPLCにより得られたそれぞ れのピーク面積により検討した (Fig. 2).ここではフェ ノールに着目してその最大ピークを与えるジアゾニウム 塩の濃度, $1 \times 10^{-5} \mathrm{~mol} \mathrm{dm}^{-3}$ を添加条件とした。

種々のフェノールとジアゾニウム塩とのジアゾカップ リング反応は $\mathrm{pH}$ によって大きく影響を受けた。 $\mathrm{pH}$ 条 件により生成するアゾフェノールのピーク面積は Fig. 3 に示すようにフェノールとクロロフェノール, クレゾー ルとエチルフェノール，キシレノールの三つの異なるパ ターンを示した. 又, $\mathrm{pH}$ 条件によっては副反応ピーク が出現するため, 反応 $\mathrm{pH}$ 条件を 10.5 とした.

反応時間を検討した結果, 上記の条件で 3 分間以上 でピークは最大となった。

\section{$3 \cdot 3$ イオン会合反応の諸条件の検討}

イオン会合反応を行う際にも $\mathrm{pH}$ の影響を大きく受 けた. ジアゾカップリング反応後そのまま $\mathrm{pH} 10.5$ の 溶液にゼフィラミンを添加したところ，一つのフェノー ルに対し複数のピークが出現した。そこで酢酸緩衝溶液 を加え $\mathrm{pH} 5$ 以下で添加したところピークは一つとなっ た. ゼフィラミン添加量を検討した結果，アゾフェノ一 


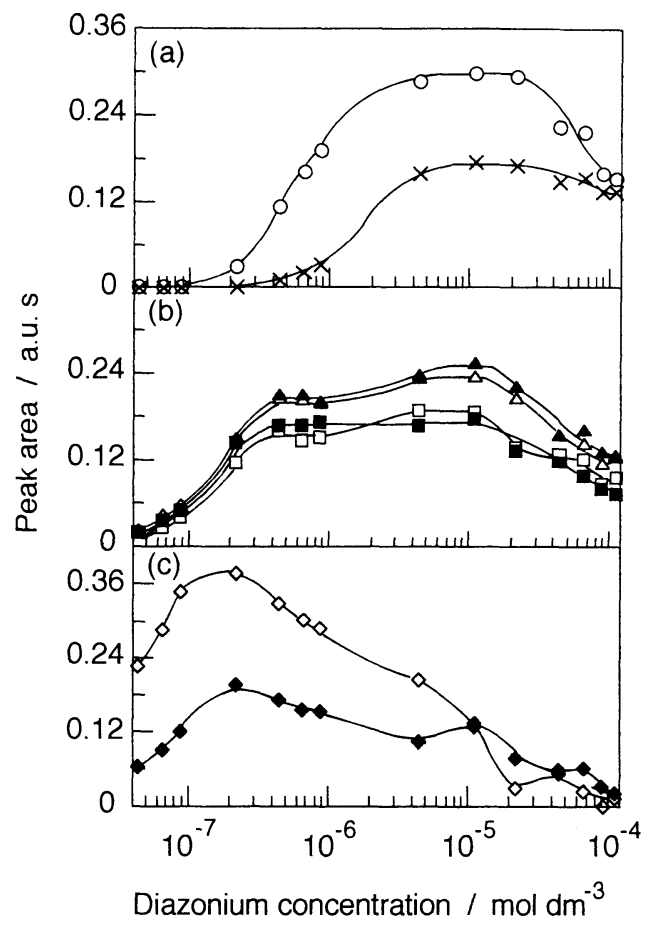

Fig. 2 Effect of diazonium concentration on the diazo-coupling reaction

Diazo-coupling reaction: $\mathrm{pH} 10.5 ;$ Zephiramine: $10^{-4} \mathrm{~mol} \mathrm{dm}^{-3}$, Ion-association reaction: $\mathrm{pH} 5$; Phenols: $30 \mu \mathrm{g} \mathrm{dm}^{-3}$; (a) $\bigcirc$ : phenol, $\quad \times: m-$ chlorophenol; (b) $\triangle$ : $m$-cresol; $\boldsymbol{\Delta}$ : $o$-cresol; $\square: m$ ethylphenol; $\mathbf{\square}$ : $o$-ethylphenol; (c) $\diamond: 2,5$-xylenol; : 2,3-xylenol

ルとほぼ等モル濃度から捕集されはじめ, $2 \times 10^{-4} \mathrm{~mol}$ $\mathrm{dm}^{-3}$ を超えるとそれぞれのピーク面積が減少した。こ れはゼフィラミンのミセル形成 ${ }^{9}$ によるイオン会合体の 可溶化のためと考えられる.

イオン会合体の凝集を形成させるためゼフィラミン添 加後 10 分間以上放置し注入することで最大のピークを 与えた。

\section{$3 \bullet 4$ HPLC の条件の検討}

移動相溶液としてゼフィラミンを含むメ夕ノールー水 及びアセトニトリル-水系混合溶液を使用し分離性能を 比較した。に゙ちらの混合溶液でも分離はできたが，メ夕 ノールー水系混合溶液ではそれぞれのピークはブロード となったため, 移動相の混合溶液にはアセトニトリルー 水系混合溶液を用いることとした. 8 種類のフェノール

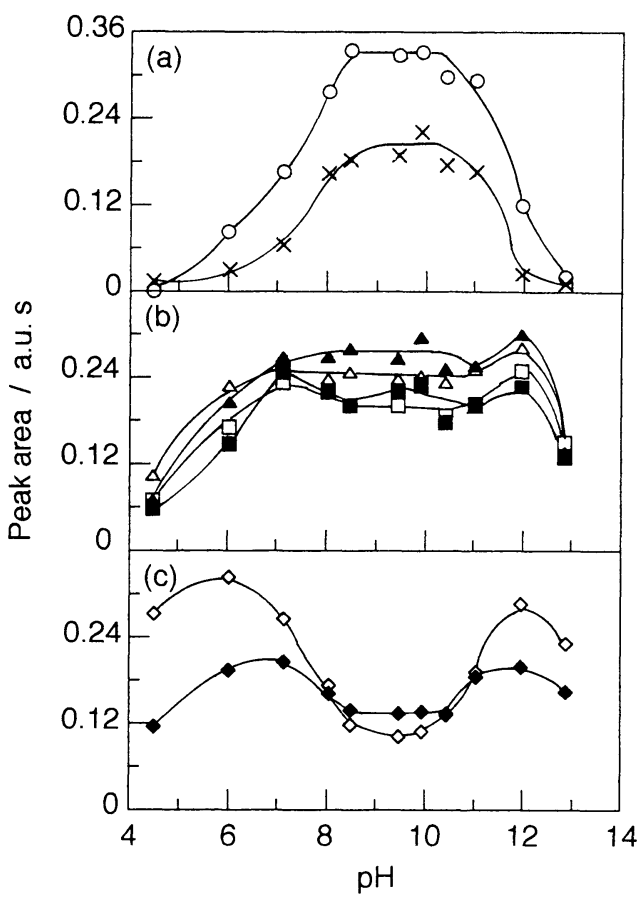

Fig. 3 Effect of $\mathrm{pH}$ on the diazo-coupling reaction Diazonium concentration: $10^{-5} \mathrm{~mol} \mathrm{dm}^{-3}$; Ionassociation reaction: $\mathrm{pH} \mathrm{5}$, Zephiramine: $10^{-4} \mathrm{~mol}$ $\mathrm{dm}^{-3}$; Phenols: $30 \mu \mathrm{g} \mathrm{dm}^{-3}$; (a) $\bigcirc$ : phenol, $\times$ : $m$-chlorophenol; (b) $\triangle$ : $m$-cresol; $\boldsymbol{\Delta}$ : $o$-cresol; $\square$ : $m$-ethylphenol; $:$ : $o$-ethylphenol; (c) $\diamond: 2,5$ xylenol; : 2,3-xylenol

類のうち最も保持時間が近接している $m$-エチルフェ ノールと 2,5-キシレノールを分離できるアセトニトリル の濃度は $37.5(\mathrm{v} / \mathrm{v}) \%, \mathrm{pH}$ 条件は 4.6 であった。 イ才 ン会合体がカラム中で再解離することを抑制するために 移動相溶液にもゼフィラミンを加え, その濃度は $1.6 \times$ $10^{-4} \mathrm{~mol} \mathrm{dm}^{-3}$ とした. 検出波長は 8 種のアゾフェ ノールの移動相溶液中の各吸収スペクトル測定の結果か ら $352 \mathrm{~nm}$ とした.

\section{$3 \cdot 5$ メンブランフィルター}

ラインフィルター内に装着するメンブランフィルター には移動相溶液によって溶解や変質しない PTFE 製を 用いた.メンブランフィルターの孔径については, 0.2 $\mu \mathrm{m}$ を用いたところ捕集率は若干向上したが数回の分析 で目詰まりを起こした． $0.5 \mu \mathrm{m}$ を用いたところ試料 1 $\mathrm{cm}^{3}$ としたとき 30 回程度の分析が可能であった. 


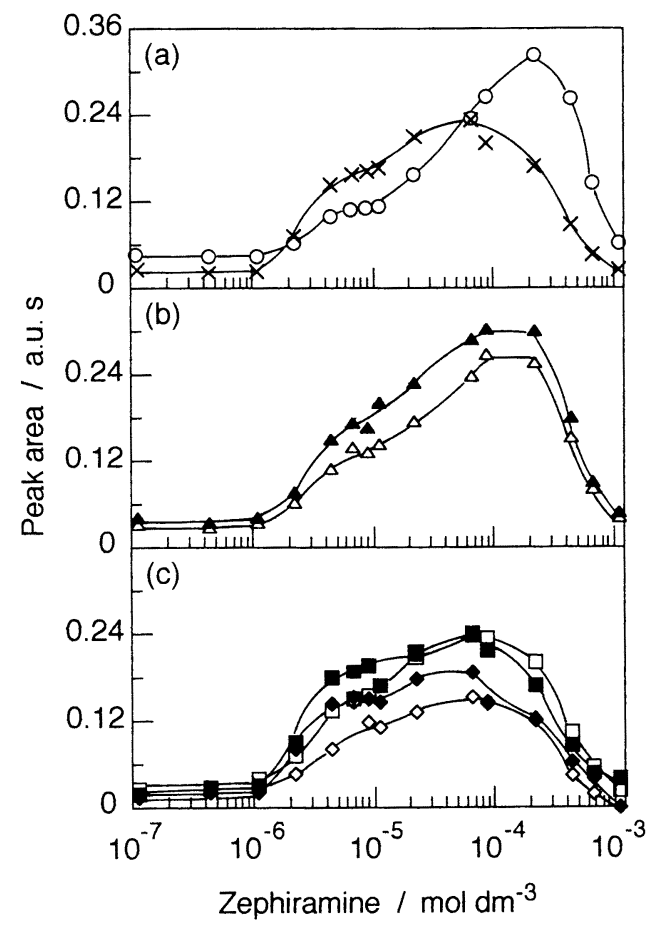

Fig. 4 Effect of Zephiramine concentration on the ion-association reaction

Diazo-coupling reaction: $\mathrm{pH}$ 10.5; Diazonium concentration: $10^{-5} \mathrm{~mol} \mathrm{dm}^{-3}$; Ion-association reaction: $\mathrm{pH}$ 5; Phenols: $30 \mu \mathrm{g} \mathrm{dm}^{-3} ;$ (a) $\bigcirc$ : phenol; $\times: m$-chlorophenol; (b) $\Delta: m$-cresol; $\boldsymbol{\Delta}$ : $o$-cresol; (c) $\square$ : $m$-ethylphenol; $\square$ : $o$-ethylphenol; $\diamond: 2,5$-xylenol; $\diamond$ : 2,3-xylenol

\section{3 •6 オンライン-ラインフィルター前濃縮法の検討}

これまで述べた条件による標準試料のクロマトグラム を Fig. 5(a) に示す. 又, 比較のため Nucleosil C-18 を 充てんしたミニカラムによる前濃縮法 (b) 及び 50 倍濃 度の標準試料を $20 \mathrm{~mm}^{3}$ ループインジェクターで注入し た場合 (c) も併せて示した. 又, それぞれ 3 回繰り返 した結果のピーク高の平均値及びループインジェクター によるピーク高を基準とした回収率を Table 1 に示 す. ミニカラム法と比較して本法は保持時間が若干短 く, 分離能が優れていた。 又, 捕集率に関しても本法の ほうが優れていた。回収率がラインフィルター濃縮にお いて $100 \%$ とならなかった。この原因は, 別の実験で $50 \mu \mathrm{g} \mathrm{dm}^{-3}$ でジアゾカップリングさせた試料及び，こ れを更に $1 \mu \mathrm{g} \mathrm{dm}^{-3}$ まで希秎した試料を用いてイオン 会合体がラインフィルターによりほほ $100 \%$ 捕集され

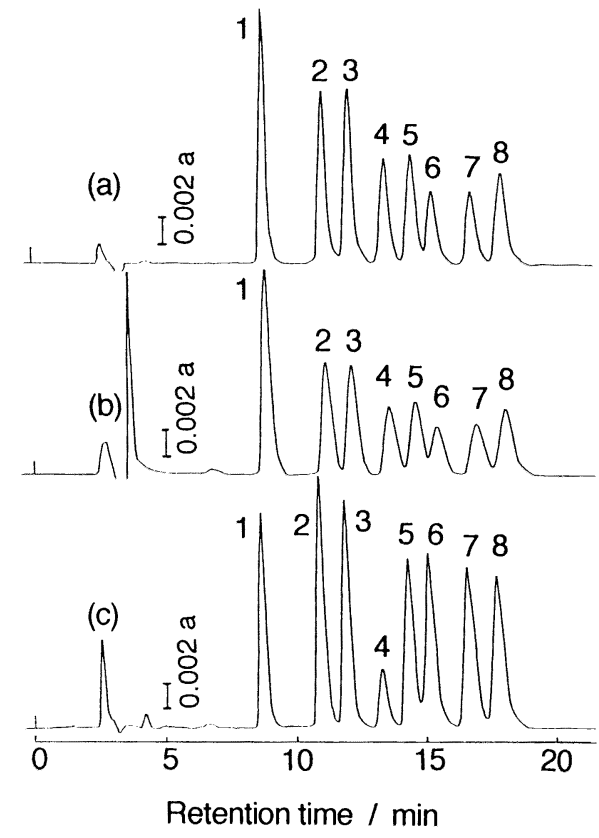

Fig. 5 Chromatograms of phenol mixture

Conditions: column, TSKgel ODS-120T (4.6 i.d. $\times$ $250 \mathrm{~mm}$ ) ; eluent, $35.7 \%$ acetonitorile $/ 62.5 \%$ water: Zephiramine, $\quad 1.6 \times 10^{-4} \mathrm{~mol} \mathrm{dm}^{-3} ; 8 \times 10^{-3} \mathrm{~mol}$ $\mathrm{dm}^{-3}$ acetate buffer, $\mathrm{pH} 4.6$; flow rate, $1 \mathrm{~cm}^{3}$ $\min ^{-1}$; column temperature, $35^{\circ} \mathrm{C}$; UV-detector, $352 \mathrm{~nm}$. (a) linefilter: phenols, $30 \mathrm{ng} \mathrm{cm}^{-3}$; sample size, $1 \mathrm{~cm}^{3}$; (b) mini-column: phenols, $30 \mathrm{ng} \mathrm{cm}^{-3}$; sample size, $1 \mathrm{~cm}^{3}$; (c) loop-injection: phenols, 1.5 $\mu \mathrm{g} \mathrm{cm}^{-3}$; sample size, $20 \mathrm{~mm}^{3}$; peaks: (1) phenol, (2) $m$-cresol, (3) $o$-cresol, (4) $m$-chlorophenol, (5) $m$ ethylphenol, (6) 2,5-xylenol, (7) 2,3-xylenol, (8) 0 ethylphenol

たことからジアゾカップリング反応の際の反忘率が濃度 により異なるためと考えられる。濃縮に際してメンブラ ンフィルターではほとんど愿みがなく表面に濃縮され, 濃縮時の拡散・分離が起こらず分離能が高くなったもの と考えられる．更に理論上非常に高い濃縮率が得られる ことも本法の有利な点である.

\section{$3 \cdot 7$ 検量線及び感度}

標準フェノ一ル混合試料をラインフィルタ一前濃縮法 によって濃縮したクロマトグラムを求め, ピーク面積に よって各々のフェノールの検量線を作成した，又，各々 $40 \mathrm{ng} \mathrm{cm}^{-3}$ のフェノールを含む混合試料 $2 \mathrm{~cm}^{3}$ を濃縮 定量した場合の相対標準偏差 $(n=4)$, 及び $2 \mathrm{~cm}^{3}$ 濃縮 
Table 1 Comparison of the pre-column concentration methods with $20 \mathrm{~mm}^{3}$ loop-injection.

\begin{tabular}{|c|c|c|c|c|c|}
\hline & \multicolumn{2}{|c|}{ Linefilter concentration $^{\dagger}$} & \multicolumn{2}{|c|}{ Mini-column concentration $^{\dagger}$} & \multirow{2}{*}{$\begin{array}{c}\text { Loop-injection }^{\dagger \dagger} \\
\text { Peak height/ } \\
\text { (Absorbance) }\end{array}$} \\
\hline & $\begin{array}{l}\text { Peak height/ } \\
\text { (Absorbance) }\end{array}$ & $\underset{\%}{\text { Recovery }}$ & $\begin{array}{l}\text { Peak height/ } \\
\text { (Absorbance) }\end{array}$ & $\underset{\%}{\text { Recovery }}$ & \\
\hline Phenol & 0.0189 & 116.6 & 0.0161 & 99.1 & 0.0162 \\
\hline$m$-Cresol & 0.0128 & 70.0 & 0.0088 & 48.1 & 0.0183 \\
\hline 0 -Cresol & 0.0130 & 75.9 & 0.0087 & 50.8 & 0.0171 \\
\hline$m$-Chlorophenol & 0.0081 & 181.4 & 0.0055 & 122.7 & 0.0045 \\
\hline$m$-Ethylphenol & 0.0085 & 67.1 & 0.0059 & 46.7 & 0.0126 \\
\hline 2,5-Xylenol & 0.0057 & 42.7 & 0.0040 & 30.3 & 0.0133 \\
\hline 2,3-Xylenol & 0.0056 & 46.4 & 0.0042 & 34.8 & 0.0120 \\
\hline$o$-Ethylphenol & 0.0068 & 59.6 & 0.0052 & 45.2 & 0.0114 \\
\hline
\end{tabular}

$\dagger$ Phenols, $30 \mu \mathrm{g} \mathrm{dm}^{-3}$; sample size, $1 \mathrm{~cm}^{3}$; concentration factor, $\times 50$. †† Phenols, $1.5 \mathrm{mg} \mathrm{dm}^{-3}$; sample size, 20 $\mathrm{mm}^{3}$

Table 2 Detection limit and relative standard deviation of the linefilter concentration

\begin{tabular}{lcc}
\hline & $\begin{array}{c}\text { Detection limit } \\
\mathrm{ng} \mathrm{dm}^{\dagger}\end{array}$ & $\begin{array}{c}\mathrm{RSD}_{\%}^{\dagger \dagger}, \\
\%\end{array}$ \\
\hline Phenol & 40 & 5.98 \\
$m$-Cresol & 72 & 1.69 \\
o-Cresol & 220 & 1.69 \\
$m$-Chlorophenol & 185 & 2.77 \\
$m$-Ethylphenol & 185 & 4.60 \\
2,5-Xylenol & 2000 & 9.76 \\
2,3-Xylenol & 500 & 9.97 \\
$o$-Ethylphenol & 250 & 1.83 \\
\hline
\end{tabular}

$\dagger S / N=3, \dagger \dagger n=4$

時の検出限界 $(S / N=3)$ はそれぞれ Table 2 に示す. フェノールについては, 環境水試料の公定法である $4-$ アミノアンチピリン吸光光度法の溶媒抽出法による高感 度化の場合よりもさらにその 10 分の 1 以下の低濃度が 検出可能であった。

\section{$3 \cdot 8$ 環境試料への応用}

本法を用いて都市排水の混入がある小河川の水に前述 の 8 種類のフェノールを標準添加し定量を行った.こ の試料を孔径 $0.5 \mu \mathrm{m}$ の PTFE 製メンブランフィルター で沪過した後, $2 \cdot 3$ の定量操作を行い直接ラインフィル ターへ濃縮したところラインフィルターに取り付けたメ ンブランフィルターの目詰まりのため濃縮できなかっ た. そこで公定法(3)4)に従い前処理操作の蒸留を行い, 併せてその回収実験を行った。その結果この河川水には フェノール類が含まれていないことが分かった．蒸留法
Table 3 Recovery of phenols from distilled water and river water by JIS-distillation method

\begin{tabular}{lcc}
\hline \multirow{2}{*}{ Phenols } & \multicolumn{2}{c}{ Recovery, $\%^{\dagger}$} \\
\cline { 2 - 3 } & Distilled water & River water \\
\hline Phenol & 97.1 & 89.1 \\
$m$-Cresol & 82.4 & 76.4 \\
$o$-Cresol & 89.2 & 0.0 \\
$m$-Chlorophenol & 106.8 & 116.3 \\
$m$-Ethylphenol & 115.4 & 115.1 \\
2,5-Xylenol & 64.6 & 0.0 \\
2,3-Xylenol & 49.3 & 0.0 \\
$o$-Ethylphenol & 91.2 & 0.0 \\
\hline
\end{tabular}

$\dagger$ Recoveries were calculated from the slopes of the standard addition lines for each of the phenols at 0 , $10,20,30 \mu \mathrm{g} \mathrm{dm}^{-3}$ in sample water based on those in distilled water, respectively.

の回収率は試料水及び蒸留水に $0,10,20,30 \mu \mathrm{g} \mathrm{dm}^{-3}$ 標準添加し, 蒸留して得られた検量線の傾きと同じ濃度 の標準試料の検量線の傾きとの比から求め Table 3 に 示した。蒸留水からの回収試験では, 2,5-キシレノ一 ル，2,3-キシレノールの回収率が低く，河川水からの回 収試験ではこれらのキシレノールのほか，o-クレゾー ル，o-エチルフェノールが全く回収されなかった。この 河川水の留出液にフェノール類を添加して定量したとこ ろ，いずれも正常値を示したことから，回収率の低下は 蒸留の際の他の共存物質の干渉, 熱分解, 又は揮散が起 こるためと考えられる. 公定法によるフェノール類の蒸 留分離法はフェノールについては一応満足すべきもの の, 他のフェノール類に対しては再検討を要するものと 
思われる.

フェノール類をアゾ色素に誘導体化し，更にこれを第 四級アンモニウム塩とのイオン会合体とし, オンライン でメンブランフィルターを装着したラインフィルターに 濃縮後 HPLC 分析する方法を確立した。公定法のよう に溶媒抽出を用いることなく $\mu \mathrm{g} \mathrm{dm}^{-3}$ 以下のフェノー ル類を数 $\mathrm{cm}^{3}$ の濃縮で容易にかつ, 分別して定量する ことができた. 又, 著者らが開発したオンラインーライ ンフィルター濃縮法は, メンブランフィルタ一表面にほ とんど厚みなく濃縮されるため理論上非常に高い濃縮倍 率が得られ, 又濃縮時の拡散・分離がされないため従来 のオンラインープレカラム固相抽出法に比べ分離効率に おいて有利であった. オンラインーラインフィルター濃 縮法は, フェノール以外の対象にもメンブランフィル タ一上に濃縮可能な誘導体化法が確立されれば応用でき る.

\section{文献}

1）合田 健編著：“水環境指標”, p. 184 (1979),（思 考社).

2) K. Kuwata, M. Uebori, Y. Yamazaki: Anal. Chem., 53, 1531 (1981).

3）JIS K 0102, 工場排水試験方法 (1993).

4) JIS K 0101, 工業用水試験方法 (1991).

5) K. Kuwata, M. Uebori, Y. Yamazaki: Anal. Chem., 52, 857 (1980).

6) 田口 茂, 系岡栄幸, 後藤克己: 分析化学, $\mathbf{3 3}, 453$ (1984)

7) 伊藤純一, 小俣雅嗣, 藤吉直明, 対馬 仁: 日化, 1993, 715 .

8）伊藤純一, 小俣雅嗣, 川崎 誠: 日本分析化学会 第 40 年会講演要旨集, p. 112 (1991).

9) J. Itoh, M. Komata: Mikrochim. Acta, 106, 109 (1992).

A new derivatization and preconcentration method for determination of trace phenols in natural water by HPLC. Jun-ichi IтоH, Yukihiro Hirosawa and Masashi Kомата (Department of Chemical System Engineering, Kitami Institute of Technology, 165, Koen-cho, Kitami-shi, Hokkaido 090)

A simple and highly effective pre-column on-line concentration method for determination of phenols by HPLC was developed. In the first step, phenols in the sample solution were converted to $\mathrm{UV}$-absorbing derivatives by coupling with 4-sulfoben-

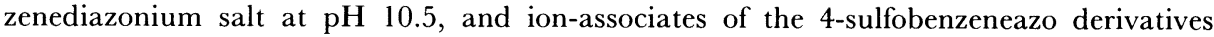
were formed with tetradecyldimethylbenzylammonium-chloride at $\mathrm{pH} 5.0$. The ionassociates were collected on a PTFE membrane filter $(6 \mathrm{~mm} \phi, 0.5 \mu \mathrm{m}$ pore size $)$ in a linefilter placed on a 6-way injection valve. The sample size (injection) was up to $3 \mathrm{~cm}^{3}$. The separation was carried out with a ODS column (Tosoh, TSKgel ODS-120T, 4.6 i.d. $\times 250 \mathrm{~mm}$ ) (column temperature $35^{\circ} \mathrm{C}$ ) and $37.5 \%$ acetonitrile $/ 62.5 \% 8.0 \times 10^{-3} \mathrm{~mol}$ $\mathrm{dm}^{-3}$ acetate buffer solution ( $\mathrm{pH} \quad 4.6$ ) containing $1.6 \times 10^{-4} \mathrm{~mol} \mathrm{dm}^{-3}$ tetradecyldimethylbenzylammonium-chloride as the mobile phase (flow rate, $1.0 \mathrm{~cm}^{3} \mathrm{~min}^{-1}$ ). A UV detector $(352 \mathrm{~nm})$ was used for monitoring. Eight phenols including phenol, $\mathrm{m}$ chlorophenol, $o-, m$-cresol, $o-, m$-ethylphenol, 2,3- and 2,5-xylenol were successfully separated and determined. Calibration plots for each of the phenols were linear up to $50 \mathrm{ng}$ $\mathrm{dm}^{-3}$. Detection limits ranged between $40 \mathrm{ng} \mathrm{dm}^{-3}$ (phenol) and $2 \mu \mathrm{g} \mathrm{dm}^{-3}(2,5-$ xylenol). The method was used for the determination of phenols in river water.

(Received June 21, 1994)

\section{Keyword phrases}

derivatization of phenols; pre-column on-line concentration method for HPLC; polytetrafluroethylene membrane filter; 4-sulfobenzenediazonium salt; tetradecyldimethylbenzylammonium-chloride. 